\title{
Comparative analysis of the patients with community-acquired pneumonia (CAP) and health care-associated pneumonia (HCAP) requiring hospitalization
}

\author{
Sibel KARA ${ }^{1}$ \\ Müșerref Şule AKÇAY ${ }^{2}$ \\ Zuhal EKICI ÜNSAL ${ }^{3}$ \\ Hatice Eylül BOZKURT \\ YILMAZ \\ Mehmet Ali HABEŞOĞLU ${ }^{3}$
}

Cite this arcticle as: Kara S, Akcay MS, Ekici Ünsal Z, Bozkurt Yılmaz HE, Habeşoğlu MA. Comparative analysis of the patients with community-acquired pneumonia (CAP) and health care-associated pneumonia (HCAP) requiring hospitalization. Tuberk Toraks 2019;67(2):108-15.

\section{Yazışma Adresi (Address for Correspondence)}

\section{Dr. Sibel KARA}

Başkent Üniversitesi Adana Dr. Turgut Noyan Uygulama ve Araştırma Merkezi,

Göğüs Hastalıkları Kliniği,

ADANA - TÜRKIYE

e-mail: sibelkarasb@hotmail.com

CCopyright 2019 by Tuberculosis and Thorax.

Available on-line at www.tuberktoraks.org.com
${ }^{1}$ Department of Chest Diseases, Baskent University Adana Dr. Turgut Noyan Application and Research Center, Adana, Turkey

${ }^{1}$ Başkent Üniversitesi Adana Dr. Turgut Noyan Uygulama ve Araştırma Merkezi, Göğüs Hastalıkları Kliniği, Adana, Türkiye

${ }^{2}$ Clinic of Chest Diseases, Baskent University, Ankara Hospital, Ankara, Turkey

2 Başkent Üniversitesi Ankara Hastanesi, Göğüs Hastalıkları Kliniği, Ankara, Türkiye

${ }^{3}$ Department of Chest Diseases, Baskent University Dr. Turgut Noyan Application and Research Center, Adana, Turkey

${ }^{3}$ Başkent Üniversitesi Adana Dr. Turgut Noyan Uygulama ve Araştırma Merkezi, Göğüs Hastalıkları Kliniği, Adana, Türkiye

\section{SUMMARY}

Comparative analysis of the patients with community-acquired pneumonia (CAP) and health care-associated pneumonia (HCAP) requiring hospitalization Introduction: The recently introduced concept of health care-associated pneumonia (HCAP), referring to patients with frequent healthcare contacts and at higher risk of contracting resistant pathogens is controversial.

Materials and Methods: A prospective study comparing patients with HCAP and community-acquired pneumonia (CAP) in the our center. The primary outcome was 30 day mortality.

Results: A total of the 169 patients HCAP 36 (21.3\%); CAP 133 (78.7\%) were evaluated. HCAP patients were older than patients with CAP [median age was 72.5 (43-96), 60.0 (18-91) years $p<0.05]$. The most common Klebsiella pneumoniae (16.6\%) and Pseudomonas aeruginosa $(8.3 \%)$ were gram-negative bacteria in the SBIP group; In the TGP group, gram-positive bacteria were more frequently isolated. Polymicrobial agents $(22.2 \%$ vs. $3.7 \% p<0.05)$ and MDR pathogens (57.1\% vs. $24 \% p<0.05)$ were more common in patients with HCAP. Mortality rate $(22.2 \%$ vs. $6 \% p<0.05)$ was also higher in HCAP more than CAP.

Conclusion: HCAP was common among patients with pneumonia requiring hospitalization and mortality rate was high. The patients with HCAP were different from CAP in terms of demographic and clinical features, etiology, outcome.

Key words: Community-acquired pneumonia; health care-associated pneumonia; prognosis; mortality 


\section{ÖZET}

Hastanede yatış gerektiren toplumda gelişen pnömoni ve sağlık bakımı ilişkili pnömonili olguların karşılaştırmalı analizi

Giriş: Sağlık bakımı ilişkili pnömoni (SBiP) sağlık hizmetleriyle sık temas eden hastalarda ortaya çıkan ve dirençli patojen riskinin daha yüksek olduğu pnömoni olarak tanımlanır. Bu çalışma hastaneye yatış gerektiren toplumda gelişen pnömoni (TGP) ve SBiP hastalarının karşılaştırılması amacıyla planlanmıştır.

Materyal ve Metod: Bu prospektif çalışmaya Haziran 2015-Aralık 2016 tarihleri arasında pnömoni ile yatırılan hastalar dahil edildi. Tüm hastalar TGP ve SBiP olarak sınıflandırıldı. Gruplar demografik ve klinik özellikleri, hastalık şiddeti, etken patojen dağılımları, prognoz ve mortalite açısından karşılaştırıldı.

Bulgular: Toplam 169 hasta [SBiP 36 (\%21.3); TGP 133 (\%78.7)] değerlendirildi. SBiP için son 90 günde 2 gün veya daha uzun süre yatış öyküsü (\%77.8) en sık risk faktörüydü. SBiP hastaları TGP'li hastalardan daha yaşlı [medyan yaş 72.5 (43-96), 60.0 (18-91) yıl $p<0.05$ ] idi ve majör komorbidite önemli derecede yüksekti [sırasıly; 97.8, \%60.9 p< 0.05]. SBiP grubunda en sık görülen patojenler gram-negatif bakteriler [Klebsiella pneumoniae (\% 16.6) ve Psödomonas aeruginosa (\%8.3)]. SBiP'li hastalarda polimikrobiyal ajanlar [\%22.2'ye karşı \%3.7 p<0.05] ve MDR patojenleri [\%57.1'e karşı \%24 p<0.05] daha sıktı. TGP grubunda ise gram-pozitif bakteriler daha sık izole edildi. Mortalite oranı SBiP'te, TGP'ten daha yüksekti [sırasıla; \% $22.2 \% 6$ p< 0.05].

Sonuç: SBIP, hastaneye yatışı gerektiren pnömonili hastalarda yaygındı ve mortalite oranı yüksekti. SBiP'li hastalar yaş, komorbidite, mikrobiyolojik ajanların dă̆ılımı ve MDR patojen açısından TGP'den farklıydı. Bu nedenle hastaneye başvuran tüm pnömoni hastaları ayrıntılı olarak sorgulanmalı ve tedavi planlamasında dirençli mikroorganizmalar göz önünde bulundurulmalıdır.

Anahtar kelimeler: Toplumda gelişen pnömoni, sağlık bakımı ilişkili pnömoni; prognoz; mortalite

\section{INTRODUCTION}

Pneumonia is evaluated under two topics according to the origin as community-acquired pneumonia (CAP) and hospital-acquired pneumonia (HAP). Health care-associated pneumonia (HCAP) is pneumonia in patients who are directly and closely related to the health care system. Although HCAP is basically community-acquired, it has included this group since it has similarity to HGP in terms of the distribution of factors and prognosis $(1,2)$. The recently, HCAP has not been included in the guideline on the "Management of hospital-acquired pneumonia and ventilator-associated pneumonia in adults" revised in 2016 by the "Infectious Diseases Society of America/American Thoracic Society (IDSA/ATS)". This opinion has been based on the facts that HCAP are usually community-acquired, there are increasing evidences that the patients are not at high risk for multidrug-resistant (MDR) pathogens and in addition, underlying patient characteristics as well are the critical determinants for susceptibility to MDR pathogens (3). HCAP was determined that it differs from CAP in terms of risk factors, causative agent distribution and prognosis depending on the characteristics of the country where the studies have been conducted and that it has high rates of mortality and morbidity $(4,5)$. For this reason, this concept has been controversial.

In Turkey, where guidelines for diagnosis and treatment with proven currency and validity have not been established yet, studies evaluating this group are limited in number, and there is no prospective study. We aimed to compare the demographic and clinical features, disease severity, etiologic distributions, prognosis and mortality of CAP and HCAP cases.

\section{MATERIALS and METHODS}

This prospective study conducted the patients hospitalized with pneumonia between June 2015-December 2016 in the our center. Our study protocol was approved by Başkent University Medical and Health Sciences Clinical Research Ethics Committee (2015-no: 15/46).

\section{Definition of Community-Acquired Pneumonia and Healthcare-Associated Pneumonia}

The patients has presented with newly developed infiltration on the chest X-Ray and at least three or more of the accompanying symptoms such as cough, sputum, fever, chest pain, shortness of breath and/or signs consistent with pneumonia on physical examination were considered as pneumonia (6). Health care-associated pneumonia was defined according to the 2005 IDSA/ATS criteria. Patients meeting any of these criteria were classified as having $\operatorname{HCAP}(1)$.

1. Hospitalization for 2 days or more in the preceding 90 days,

2. Resident of a nursing home or extended-care facility, 
3. Home infusion therapy (including antibiotics), also includes patients with long-term indwelling devices such as catheters),

4. Chronic dialysis within 30 days,

5. Home wound care,

6. Family member with multidrug-resistant pathogen.

The evaluated patients were categorized either as TGP or as SBIP.

\section{Clinical Evaluation and Assessment of Disease Severity}

All cases were interviewed with face-to-face interviews and signed. Health care risks, demographic characteristics, comorbidities, pneumococcal and influenza vaccination, the risk of aspiration pneumonia (dysphagia, cerebrovascular disease, presence of Alzheimer disease and/or dementia), esophagus pathologies, enteral feeding through a percutaneous endoscopic gastrostomy (PEG) or nasogastric catheter (NGC), and empirical antibiotic therapy received before hospitalization as well as clinical and radiological findings were recorded.

The follow-up of the cases in clinical or intensive care unit and CURB-65 score, pneumonia severity score (PSI) were assessed using international and national pneumonia guidelines (7-9). After all cases were admitted to the hospital, two mediocre blood cultures, sputum cultures, legionella antigen and laboratory tests ( 1 and 4 days) were studied. When necessary, deep tracheal aspiration, bronchoscopic bronchoalveolar lavage culture and nasal or nasopharyngeal swab specimens were taken for respiratory virus detection in selected patients.

Pneumonia treatments were applied according to the recommendations of the Turkish Thoracic Society Pneumonia Consensus Report (7).

\section{Clinical Course and Outcomes}

The patients were followed for 30 days after hospitalization. In terms of prognosis, duration of hospitalization, need for invasive mechanical ventilation (IMV), duration of IMV and mortality rates in the intensive care unit (ICU) were recorded.

\section{STATISTICAL ANALYSIS}

Statistical analysis of the data was done using SPSS 17.0 package program. Categorical measurements were summarized as number and percentage, whereas continuous measurements were summarized as mean and standard deviation (median and minimum-maximum, where necessary). Chi-square test or Fisher's test statistics was used for the comparison between categorical variables. Comparison of continuous variables between the groups was done by independent group t-test for the variables meeting the condition for parametric distribution and by Mann Whitney $U$ test for the variables not meeting the condition for parametric distribution. The level of statistical significance was predetermined to be $\mathrm{p}<0.05$.

\section{RESULTS}

A total of 169 patients were evaluated HCAP 36 (21.3\%); CAP 133 (78.7\%). The history of hospitalization for at least two days in the last 90 days $(77.8 \%)$ was the most common risk factor for HCAP (Table 1).

In the demographic characteristics comparison, patients with HCAP were older than the patients with CAP. Patients with HCAP, including cerebrovascular disease, solid tumor and Alzheimer according to CAP had significant major comorbidity. With regard to the clinical findings; confusion was more common among HCAP patients. In addition; patients with HCAP had more risk factors for aspiration pneumonia. Patients with HCAP had higher procalcitonin and creatinine values. No statistically significant difference was determined between groups in other laboratory findings (Table 2).

\section{Microbiologic Distribution}

A positive microbiological diagnosis was made in $55.5 \%$ of patients with HCAP compared with $27.8 \%$ patients with CAP. The frequencies of the organisms isolated in both groups are shown in (Table 3). The

Table 1. Risk factors for healthcare-associated pneumonia

$\begin{array}{lc}\begin{array}{l}\text { Hospitalization for } 2 \text { days or more in the } \\ \text { preceding } 90 \text { days }\end{array} & 28(77.8 \%) \\ \begin{array}{l}\text { Care for pressure ulcer at home } \\ \text { Chronic dialysis within } 30 \text { days }\end{array} & 8(22.3 \%) \\ \begin{array}{l}\text { Resident of a nursing home or } \\ \text { extended-care facility }\end{array} & 7(19.5 \%) \\ \begin{array}{l}\text { Home infusion therapy (including } \\ \text { antibiotics) }\end{array} & 1(2.4 \%) \\ \begin{array}{l}\text { Family member with multidrug-resistant } \\ \text { pathogen }\end{array} & 1(2.8 \%)\end{array}$

More than a single risk factor were determined in 11 cases; thus the number is $>36$ and percentage is $>100 \%$. 
Table 2. Baseline demographic and illness severity

\begin{tabular}{|c|c|c|c|c|}
\hline \multicolumn{2}{|l|}{ 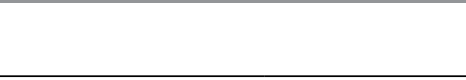 } & $\begin{array}{c}\text { HCAP patients } \\
n=36(\%)\end{array}$ & $\begin{array}{c}\text { CAP } \\
\text { Patients } n=133(\%) \\
\end{array}$ & $\mathbf{p}$ \\
\hline \multicolumn{2}{|l|}{ Age (year) } & $72.5(43-96)$ & $60(18-91)$ & $<0.05$ \\
\hline \multicolumn{2}{|l|}{ Age $>65$ years } & $27(71)$ & $51(38.3)$ & $<0.05$ \\
\hline \multicolumn{2}{|l|}{ Male } & $24(66.7)$ & $87(65.4)$ & 0.888 \\
\hline \multicolumn{2}{|c|}{ Influenza vaccination $(+)$} & $7(19.4)$ & $28(21.1)$ & 0.850 \\
\hline \multicolumn{2}{|c|}{ Pneumococcal vaccination $(+)$} & $2(5.6)$ & $7(5.3)$ & 0.871 \\
\hline \multicolumn{2}{|l|}{ Confusion } & $11(30.6)$ & $8(6.0)$ & $<0.05$ \\
\hline \multicolumn{2}{|l|}{ Major comorbidity } & $35(97.8)$ & $81(60.9)$ & $<0.05$ \\
\hline \multicolumn{2}{|l|}{ Solid tumor } & $10(27.7)$ & $5(3.7)$ & $<0.05$ \\
\hline \multicolumn{2}{|c|}{ Cerebrovascular disease } & $10(27.7)$ & $5(3.7)$ & $<0.05$ \\
\hline \multicolumn{2}{|l|}{ Alzheimer disease } & $5(14)$ & $1(0.8)$ & $<0.05$ \\
\hline \multicolumn{2}{|l|}{ Parkinson disease } & $2(5.6)$ & $1(0.8)$ & 0.052 \\
\hline \multicolumn{2}{|c|}{ Motor neuron disease } & $2(5.6)$ & - & 0.487 \\
\hline \multicolumn{2}{|c|}{ Chronic pulmonary disease } & $7(19.7)$ & $38(28.5)$ & 0.946 \\
\hline \multicolumn{2}{|c|}{ Congestive heart failure } & $6(16.6)$ & $18(13.5)$ & 0.633 \\
\hline \multicolumn{2}{|c|}{ Chronic liver disease } & $1(2.7)$ & - & 0.487 \\
\hline \multicolumn{2}{|c|}{ Chronic renal failure } & $6(16.6)$ & $1(0.75)$ & 0.131 \\
\hline \multicolumn{2}{|l|}{ Diabetes mellitus } & $14(38.8)$ & $34(25.5)$ & 0.115 \\
\hline \multicolumn{2}{|c|}{ Probable aspiration pneumonia } & $14(38.8)$ & $1(0.8)$ & $<0.05$ \\
\hline \multicolumn{2}{|c|}{ Feeding through a PEG } & $3(8.3)$ & - & $<0.05$ \\
\hline \multicolumn{2}{|c|}{ Feeding through a NGC } & $3(8.3)$ & - & $<0.05$ \\
\hline \multicolumn{2}{|c|}{ Dysphagia } & $6(16.7)$ & $1(0.8)$ & $<0.05$ \\
\hline \multicolumn{2}{|c|}{ Empirical antibiotic use } & $5(13.9)$ & $27(20.3)$ & 0.364 \\
\hline \multicolumn{2}{|c|}{ Inappropriate empirical antibiotic use } & $3(8.3)$ & $19(14.3)$ & 0.344 \\
\hline \multicolumn{2}{|c|}{ Pneumonia Severity Index } & $4.1 \pm 1.12$ & $8 \pm 1.3$ & $<0.05$ \\
\hline \multicolumn{2}{|l|}{ CURB-65 } & $1.8 \pm 1.20$ & $0.8 \pm 0.7$ & $<0.05$ \\
\hline Leukocyte $\left(/ \mathrm{mm}^{3}\right)$ & $\begin{array}{l}\text { Day } 1 \\
\text { Day } 4\end{array}$ & $\begin{array}{c}12.20(3.50-26.60) \\
8.87(1.4-20.7)\end{array}$ & $\begin{array}{c}11.20(1.290-47.5) \\
7.9(1.05-28.4)\end{array}$ & $\begin{array}{l}0.208 \\
0.225\end{array}$ \\
\hline $\mathrm{CRP}(\mathrm{mg} / \mathrm{dL})$ & $\begin{array}{l}\text { Day } 1 \\
\text { Day } 4\end{array}$ & $\begin{array}{l}122(7.3-216) \\
62.0(6.3-216)\end{array}$ & $\begin{array}{l}137(7.3-261) \\
54.0(3.3-216)\end{array}$ & $\begin{array}{l}0.081 \\
0.698\end{array}$ \\
\hline PCT (ng/dL) & $\begin{array}{l}\text { Day } 1 \\
\text { Day } 4\end{array}$ & $\begin{array}{l}0.96(0.05-68.2) \\
0.55(0.02-65.8)\end{array}$ & $\begin{array}{c}0.31(0.001-51.4) \\
0.17(0.00-6.69)\end{array}$ & $\begin{array}{l}<0.05 \\
<0.05\end{array}$ \\
\hline Creatinine $(\mathrm{g} / \mathrm{dL})$ & $\begin{array}{l}\text { Day } 1 \\
\text { Day } 4\end{array}$ & $\begin{array}{l}1.15(0.29-6.5) \\
0.94(0.16-6.8)\end{array}$ & $\begin{array}{l}0.80(0.30-3.9) \\
0.70(0.16-3.2)\end{array}$ & $\begin{array}{l}<0.05 \\
<0.05\end{array}$ \\
\hline
\end{tabular}

most common gram-negative bacteria in the HCAP group ( $K$. pneumoniae $(16.6 \%$ ) and $P$. aeruginosa $(8.3 \%)$; in the CAP group, gram-positive bacteria (Coagulase negative Staphylococci (7.3\%) and Streptococcus pneumoniae (3\%) were more frequently isolated. Polymicrobial pathogens and multidrugresistant bacteria were found higher in with HCAP patients than that in with CAP. Respiratory viruses were isolated in 17 (12.5\%) patients with CAP. 
Table 3. Microbiological findings of HCAP and CAP patients

\begin{tabular}{|lccc|} 
& HCAP & CAP & $\mathbf{p}$ \\
\hline Gram negative pathogens & $\mathbf{n = 3 6}$ & $\mathbf{n = 1 3 3}$ & $<0.05$ \\
Pseudomonas aeruginosa & $18(50)$ & $12(9.8)$ & $<0.05$ \\
Acinetobacter baumannii & $3(8.3)$ & $1(0.75)$ & 0.220 \\
Klebsiella pneumoniae & $2(5.5)$ & $1(0.75)$ & $<0.05$ \\
Escherichia coli & $6(16.6)$ & $2(1.5)$ & 0.111 \\
Non fermentative gram-negative bacillus & $3(8.3)$ & $2(1.5)$ & 0.896 \\
Serratia marcescens & $1(2.7)$ & $1(0.75)$ & 0.220 \\
Haemophilus influenzae & $2(5.5)$ & $1(0.75)$ & 0.843 \\
Legionella pneumophila (urine) & - & $3(2.2)$ & 0.601 \\
Proteus mirabilis & - & $1(0.75)$ & 0.482 \\
Gram-positive pathogens & $1(2.7)$ & - & $<0.05$ \\
MSSA & $10(27.7)$ & $13(9.8)$ & 0.220 \\
Coagulase-negative staphylococci & $2(5.5)$ & $1(0.75)$ & 0.222 \\
Streptococcus pneumoniae & $5(13.8)$ & $8(7.3)$ & 0.341 \\
Respiratory viruses & $3(8.3)$ & $4(3.0)$ & $<0.05$ \\
Polymicrobialetiology & - & $17(12.7)$ & $<0.05$ \\
MDR agents & $8(22.2)$ & $5(3.7)$ & $<0.05$ \\
Pathogens identified & $16(57.1)$ & $6(24)$ & $<0.05$ \\
\hline All parameters were presented as; $\mathrm{n}:$ Number of patients (\%). HCAP: Health care-associated pneumonia, CAP: Community-acquired pneumonia, \\
MSSA: Methicillin-sensitive Staphylococcus aureus, MDR: Multidrug resistant. & & \\
\hline
\end{tabular}

Table 4. Clinical courses of CAP and HCAP cases

\begin{tabular}{|lccc|} 
& HCAP & CAP & p \\
\hline Duration of hospital stay (day) & $7.1 \pm 4.4$ & $6.4 \pm 4.0$ & 0.163 \\
Need for ICU & $18(50 \%)$ & $38(28.6 \%)$ & $<0.05$ \\
Duration of ICU stay (day) & $6.2 \pm 4.9$ & $4.2 \pm 3.2$ & 0.249 \\
IMV therapy & $7(19.4 \%)$ & $9(6.8 \%)$ & 0.470 \\
Duration of mechanical ventilation (day) & $4.7 \pm 3.5$ & $4.1 \pm 4.0$ & 0.673 \\
Mortality rate & $8(22.2 \%)$ & $8(6 \%)$ & $<0.05$ \\
\hline
\end{tabular}

Values are presented as; $\mathrm{n}$ : Number of patients (\%), median (minimum- maximum), mean \pm standard deviation (SD). HCAP: Health care-associated pneumonia, CAP: Community-acquired pneumonia, ICU: Intensive care unit, IMV: Invasive mechanical ventilator.

\section{Severity of Pneumonia and Clinical Outcomes}

Initial severities as measured by the PSI and CURB-65 were significantly higher in patients with HCAP than in those with CAP, and the probability of aspiration pneumonia was more frequent in patients with HCAP (Table 2). Need for IUC was also more frequent among HCAP patients. Mortality rate was higher in HCAP $(22.2 \%)$ than CAP $(6 \%)$ group. The overall 30 day mortality rate was $16(9.5 \%)$. No statistical significant difference was determined between the groups in terms of need for mechanical ventilatory support and duration of mechanical ventilation, which was averagely 4 days (Table 4 ).

In this study, the analysis of overall patients we revealed no statistically significant difference between the mortality rate and the risk factors such as age, the most frequent comorbidities, inappropriate empirical antibiotic therapy, CURB-65 score, enteral feeding, suspicion of aspiration, need for mechanical ventilation and duration of staying in the ICU. 


\section{DISCUSSION}

In the 2005 guideline IDSA/ATS, HCAP has been defined as the pneumonia occurring patients with frequently health care contacts and therefore has high risk of infection with MDR pathogen infection (1). Data published shortly after this guideline found that patients with HCAP had high mortality rate and organism spectrum similar to HAP rather than CAP. These findings have been confirmed in a number of studies from the United States (US) demonstrating that HCAP patients have high risk for mortality and that gram-negative organisms bacteria such as $S$. aureus and $P$. aeruginosa are the agents isolated more frequently (10-12). However, this issue has become controversial because studies in Europe have described a more similar microbiological spectrum to CAP (13-15). Additionally, in the recent studies there is increasing evidence that many patients diagnosed with HCAP are not at high risk for MDR pathogens (16-20).

Our aim in this study was to investigate the differences in etiology and outcomes between patients with HCAP and those with CAP.

Among the major findings, HCAP was common, accounted for $21.3 \%$ of hospitalized patients with pneumonia. The frequency of HCAP were similar to that previous studies in England (20.5\%), United States $(21.9 \%)$, Spain $(17.3 \%)$ and Italy $(24.9 \%)$ $(4,10,21,22)$.

We determined that the most important risk factor in patients with HCAP to be hospitalization for 2 days or more in the preceding 90 days. This result is similar to the study conducted in Turkey by Taşbakan et al. but different from the study conducted in the US demonstrating that half of the patients have been resident of a nursing home $(10,23)$. This may be due to the fact that the number of patients in resident of a nursing home is not high in the region where we live.

In the present study, overall 30 day mortality rate was $9.5 \%$. As in previous studies, the mortality rate of patients with HCAP was three times that of patients with CAP. In addition, patients with HCAP had older and more frequent comorbidities than CAP $(4,23,24)$. These two are the strong prognostic factors of pneumonia. In addition, we found that patients with HCAP had more frequent risk factors (enteral feeding) for aspiration pneumonia, previously reported in a small number of studies (4).
In the study from US; methicillin resistant Staphylococcus aureus (MRSA) $30.6 \%$ and $P$. aeruginosa $25.5 \%$ were isolated in patients with HCAP (11). In retrospective study in our country; $P$. aeruginosa $(30.8 \%)$, A. baumannii $(20.5 \%)$ and MRSA $(12.8 \%)$ were reported in HCAP group. Unlike these studies, in a comparative study from Spain investigating 1328 patients, the prevalence was reported to be low of [(S. aureus $(2.4 \%)$ and gram-negative bacillus (4\%)] (13). In our study, in the patients with HCAP were at low rates, but typically the most common gram-negative bacteria; whereas in the CAP group, gram-positive bacteria were more frequently isolated. Gram-negative enteric bacteria or MRSA was not isolated in any of the groups. Our study was limited due to the low number of such pathogens identified. This may be related to the low number of patients enrolled. Additionaly, respiratory viruses were isolated in $12.5 \%$ of patients with CAP; this was attributed to the Influenza A (H1 N1) outbreak in the 2015-2016 winter season when the study was conducted.

Recent hospitalization of patients with HCAP leads to infection with resistant bacteria by causing colonization of MDR pathogen. In the study conducted by Shorr et al., MDR pathogens rate was reported as $48.6 \%$ (12). In our study, MDR pathogens rate in HCAP was $57.1 \%$. This may be related to the fact that the most common risk factor we identified in the HCAP group was hospitalization for 2 days or more in the preceding 90 days. Besides, similar to previous studies, we found that patients with HCAP had a higher polymicrobial agent $(4,24)$.

Previously studies found that that patients with HCAP were required more frequent need for ICU than patients with CAP $(10,11,25)$. In this study, patients with HCAP had higher intensive care needs than those with CAP.

However, statistical analysis revealed no significant relationship between all these factors and mortality rate (after adjusting for age and for the other variables). This might be due to the limited number of HCAP patients. We think that multicenter studies are required on this subject.

Contrary to the opinion in the new guideline, we found that more gram-negative pathogens were isolated in the HCAP group, but also because of the high rate of polymicrobial and MDR agents; we think 
that this group should be considered as a separate group from the CAP and its treatment should be arranged accordingly (3).

In conclusion, HCAP is common among pneumonia patients requiring hospitalization. HCAP patients differ from the CAP patients in terms of age, comorbidity, presenting disease severity, causative agent distribution, polymicrobial etiology, multidrug resistance status, and mortality. All pneumonia cases admitted to the hospital, therefore, need to be questioned in detail for the risk factors HCAP and treatment should be planned accordingly.

\section{CONFLICT of INTEREST}

All authors have no conflict of interests.

\section{AUTHORSHIP CONTRIBUTIONS}

Concept/Design: All of authors.

Analysis/Interpretation: All of authors.

Data Acquisition: All of authors.

Writting: All of authors.

Critical Revision: All of authors.

Final Approval: All of authors.

\section{REFERENCES}

1. American Thoracic Society, Infectious Diseases Society of America. Guidelines for the management of adults with hospital-acquired, ventilator-associated, and healthcareassociated pneumonia. Am J Respir Crit Care Med 2005; 171:388-416.

2. Mandell L, Wunderink RG, Anzueto A, Bartlett JG, Campbell GD, Dean NC, et al. Infectious Diseases Society of America/American Thoracic Society Consensus Guidelines on the Management of Community-Acquired Pneumonia in Adults. CID 2007;44:29-72.

3. Kalil AC, Metersky ML, Klompas M, Muscedere J, Sweeney $D A$, Palmer LB, et al. Management of Adults With Hospital-acquired and Ventilator-associated Pneumonia: 2016 Clinical Practice Guidelines by the Infectious Diseases Society of America and the American Thoracic Society. Clin Infect Dis 2016;3:e61-e111.

4. Vallés I, Martin-Loeches I, Torres A, Diaz E, Seijas I, López MJ, et al. Epidemiology, antibiotic therapy and clinical outcomes in healthcare-associated pneumonia: a uk cohort study. Clin Infect Dis 2011;53:107-13.

5. Falcone $M$, Venditti $M$, Shindo $Y$, Kollef $M H$. Healthcareassociated pneumonia: diagnostic criteria and distinction from community-acquired pneumonia. International Journal of Infectious Diseases 2011;15:545-50.
6. Carratalà J, Fernandez-Sabe N, Ortega L, Castellsagué X, Roson B, Dorca J, et al. Outpatient care compared with hospitalization for community-acquired pneumonia: a randomized trial in low-risk patients. Ann Intern Med 2005; 142:165-72.

7. Kılıç O, Ece T, Arman D, Bacakoğlu F, Çakar N, Çakır N ve ark. Türk Toraks Derneği Erişkinlerde Hastanede Gelişen Pnömoni Tanı ve Tedavi Uzlaşı Raporu. Türk Toraks Dergisi 2009; 10:1-17.

8. Chalmers JD, Singanayagam A, Akram AR, Mandal P, KIsa ÖP, Choudhury G, et al. Severity assessment tools for predicting mortality in hospitalized patients with community acquired pneumonia: systematic review and meta-analysis. Thorax 2010;65:878-83.

9. Lim WS, van der Eerden MM, Laing R, Boersma WG, Karalus N, Town Gl, et al. Defining community acquired pneumonia severity on presentation to hospital: an international derivation and validation study. Thorax 2003;58: 377-82.

10. Kollef MH, Shorr A, Tabak YP, Gupta V, Liu LZ, Johannes $R S$. Epidemiology and outcomes of healthcare-associated pneumonia: results from a large US database of culturepositive pneumonia. Chest 2005;128:3854-62.

11. Micek ST, Kollef KE, Reichley RM, Roubinian N, Kollef MH. Healthcare- associated pneumonia and communityacquired pneumonia: a single-center experience. Antimicrob Agents Chemother 2007; 51:3568-73.

12. Shorr AF, Zilberberg MD, Micek ST, Kollef MH. Prediction of infection due to antibiotic-resistant bacteria by select risk factors for health care-associated pneumonia. Arch Intern Med 2008;168:2205-10.

13. Carratalà J, Mykietiuk A, Fernández-Sabé N, Suárez C, Dorca J, Verdaguer, et al. Healthcare-associated pneumonia requiring hospital admission: epidemiology, antibiotic therapy and clinical outcomes. Arch Intern Med 2007; 167:1393-9.

14. Venditti $M$, Falcone $M$, Corrao S, Licata G, Serra P. Outcomes of patients hospitalized with communityacquired, health care-associated, and hospital-acquired pneumonia. Ann Intern Med 2009;150:19-26.

15. Ewig S, Welte T, Chastre J, Torres A. Rethinking the concepts of community-acquired and healthcareassociated pneumonia. Lancet Infect Dis 2010;10:279-87.

16. Chalmers JD, Rother C, Salih W, Ewig S. Healthcareassociated pneumonia does not accurately identify potentially resistant pathogens: a systematic review and meta-analysis. Clin Infect Dis 2014;58:330-9.

17. Gross AE, Van Schooneveld TC, Olsen KM, Rupp ME, Bui $T H$, Forsung $E$, et al. Epidemiology and predictors of multidrug-resistant community-acquired and healthcare-associated pneumonia. Antimicrob Agents Chemother 2014;58:5262-8. 
18. Yap V, Datta D, Metersky ML. Is the present definition of healthcare-associated pneumonia the best way to define risk of infection with antibiotic-resistant pathogens? Infect Dis Clin North Am 2013;27:1-18.

19. Jones $B E$, Jones $M M$, Huttner B, Stoddard G, Brown KA, Stevens VW, et al. Trends in antibiotic use and nosocomial pathogens in hospitalized veterans with pneumonia at 128 medical centers, 2006-2010. Clin Infect Dis 2015;61:1403-10.

20. Vallés J, Martin-Loeches I, Torres A, Diaz E, Seijas I, López $M J$, et al. Epidemiology, antibiotic therapy and clinical outcomes of healthcare-associated pneumonia in critically ill patients: a Spanish cohort study. Intensive Care Med 2014;40:572-81.

21. Carratalà J, Mykietiuk A, Fernández-Sabé N, Suárez C, Dorca J, Verdaguer, et al. Healthcare-associated pneumonia requiring hospital admission: epidemiology, antibiotic therapy, and clinical outcomes. Arch Intern Med 2007; 167:1393-9.
22. Venditti $M$, Falcone $M$, Corrao $S$, Licata $G$, Serra $P$ Outcomes of patients hospitalized with communityacquired, healthcare-associated and hospital-acquired pneumonia. Ann Intern Med 2009;150:19-26.

23. Taşbakan MS, Bacakoğlu F, Başoğlu OK, Gürgün A, Başarik B, Citim Tuncel $S$, et al. The comparison of patients with hospitalized healthcare-associated pneumonia to community-acquired pneumonia. Tuberk Toraks 2011;59:348-54.

24. Gil Myung Seong, Miok Kim, Jaechun Lee, Jong Hoo Lee, Sun Young Jeong, Yunsuk Choi, et al. Healthcare-associated pneumonia among hospitalized patients: Is it different from community acquired pneumonia? Tuberc Respir Dis (Seoul) 2014;76:66-74.

25. Shindo $Y$, Sato $S$, Maruyama E, Ohashi T, Ogawa $M$, Hashimoto $N$, et al. Healthcare-associated pneumonia among hospitalized patients in a Japanese community hospital. Chest 2009;135:633-40. 